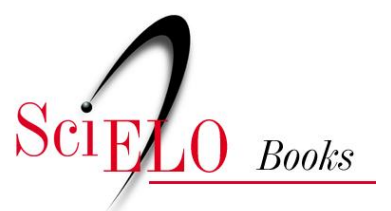

\title{
III. O mandato da raça negra
}

\author{
Joaquim Nabuco
}

\section{SciELO Books / SciELO Livros / SciELO Libros}

NABUCO, J. O mandato da raça negra. In: O abolicionismo [online]. Rio de Janeiro: Centro Edelstein de Pesquisas Sociais, 2011. O mandato da raça negra. pp. 13-17. ISBN: 978-85-7982-070-0. https://doi.org/10.7476/9788579820700.0004.

\section{() Poviuc}

This work is free of known copyright restrictions. http://creativecommons.org/publicdomain/mark/1.0/

Este trabalho está livre de restrições de direito de autor e/ou de direitos conexos conhecidas.

http://creativecommons.org/publicdomain/mark/1.0/

Esta obra está libre de restricciones conocidas de derechos autorales. http://creativecommons.org/publicdomain/mark/1.0/ 


\section{O MANDATO DA RAÇA NEGRA}

Se a inteligência nativa e a independência dos bretões não conseguem sobreviver no clima insalubre e adverso da escravidão pessoal, como se poderia esperar que os pobres africanos, sem o apoio de nenhum sentimento de dignidade pessoal ou de direitos civis, não cedessem às influências malignas a que há tanto tempo estão sujeitos e não ficassem deprimidos mesmo abaixo do nível da espécie humana?

William Wilbeforce

O mandato abolicionista é uma dupla delegação, inconsciente da parte dos que a fazem, mas, em ambos os casos, interpretada pelos que a aceitam como um mandato a que não se pode renunciar. Nesse sentido, deve-se dizer que o abolicionista é o advogado gratuito de duas classes sociais que, de outra forma, não teriam meios de reivindicar os seus direitos, nem consciência deles. Essas classes são: os escravos e os ingênuos. Os motivos pelos quais essa procuração tácita impõem-nos uma obrigação irrenunciável não são puramente - para muitos não são mesmo principalmente - motivos de humanidade, compaixão e defesa generosa do fraco e do oprimido.

Em outros países, a propaganda da emancipação foi um movimento religioso, pregado do púlpito, sustentando com fervor pelas diferentes igrejas e comunhões religiosas. Entre nós, o movimento abolicionista nada deve, infelizmente, à Igreja do Estado; pelo contrário, a posse de homens e mulheres pelos conventos e por todo o clero secular desmoralizou inteiramente o sentimento religiosos de senhores e escravos. No sacerdote, estes não viam senão um homem que os podia comprar, e aqueles a última pessoa que se lembraria de acusá-los. A deserção, pelo nosso clero, do posto que o Evangelho lhe marcou foi a mais vergonhosa possível: ninguém o viu tomar a parte dos escravos, fazer uso da religião para suavizar-lhes o cativeiro, e para dizer a verdade moral aos senhores. Nenhum padre tentou, nunca, impedir um leilão de escravos, nem condenou o regime religiosos das senzalas. A Igreja 
Católica, apesar do seu imenso poderio em um país ainda em grande parte fanatizado por ela, nunca elevou no Brasil a voz em favor da emancipação.

Se o que dá força ao abolicionismo não é principalmente o sentimento religioso, o qual não é a alavanca de progresso que poderia ser, por ter sido desnaturado pelo próprio clero, também não é o espírito de caridade ou filantropia. A guerra contra a escravidão foi, na Inglaterra, um movimento religioso e filantrópico, determinado por sentimentos que nada tinham de político, senão no sentido em que se pode chamar política à moral social do Evangelho. No Brasil, porém, o abolicionismo é antes de tudo um movimento político, para o qual, sem dúvida, poderosamente concorre o interesse pelos escravos e a compaixão pela sua sorte, mas que nasce de um pensamento diverso: o de reconstruir o Brasil sobre o trabalho livre e a união das raças na liberdade.

Nos outros países o abolicionismo não tinha esse caráter de reforma política primordial, porque não se queria a raça negra para elemento permanente de população, nem como parte homogênea da sociedade. $O$ negro, libertado, ficaria nas colônias, não seria nunca um fator eleitoral na própria Inglaterra, ou França. Nos Estados Unidos os acontecimentos marcharam com tanta rapidez e desenharam-se por tal forma, que o Congresso se viu forçado a fazer dos antigos escravos do Sul, de um dia para o outro, cidadãos americanos, com os mesmos direitos que os demais; mas esse foi um dos resultados imprevistos da guerra. A abolição não tinha, até o momento da Emenda constitucional, tão amplo sentido, e ninguém sonhara para o negro ao mesmo tempo a alforria e o voto.

No Brasil, a questão não é, como nas colônias europeias, um movimento de generosidade em favor de uma classe de homens vítimas de uma opressão injusta a grande distância das nossas praias. A raça negra não é, tampouco, para nós, uma raça inferior, alheia à comunhão, ou isolada desta, e cujo bem estar nos afete como o de qualquer tribo indígena maltratada pelos invasores europeus. Para nós, a raça negra é um elemento de considerável importância nacional, estreitamente ligada por infinitas relações orgânicas à nossa constituição, parte integrante do povo brasileiro. Por outro lado, a emancipação não significa tão somente a termo da injustiça de que o escravo é mártir, mas também a eliminação simultânea dos dois tipos contrários, e no fundo os mesmos: o escravo e o senhor.
É esse ponto de vista, da importância fundamental da emancipação, que nos faz sub-rogar-nos nos direitos de que os escravos e os seus filhos chamados ingênuos por uma aplicação restrita da palavra, a qual mostra bem o valor das ficções que contrastam com a realidade - não podem ter consciência ou, tendo-a, não podem reclamar, pela morte civil a que estão sujeitos. Aceitamos esse mandato como homens políticos, por motivos políticos, e assim representamos os escravos e os ingênuos na qualidade de brasileiros que julgam o seu título de cidadão diminuído enquanto houver brasileiros escravos, isto é, no interesse de todo o país e no nosso próprio interesse.

Quem pode dizer que a raça negra não tem direito e protestar perante o mundo e perante a história contra o procedimento do Brasil? A esse direito de acusação, entretanto, ela própria renunciou; ela não apela para o mundo, mas tão somente para a generosidade do país que a escravidão lhe deu por pátria. Não é já tempo que os brasileiros prestem ouvidos a esse apelo?

Em primeiro lugar, a parte da população nacional que descende de escravos é, pelo menos, tão numerosa como a parte que descende exclusivamente de senhores; a raça negra nos deu um povo. Em segundo lugar, o que existe até hoje sobre o vasto território que se chama Brasil foi levantado ou cultivado por aquela raça; ela construiu o nosso país. Há trezentos anos que o africano tem sido o principal instrumento da ocupação e da manutenção do nosso território pelo europeu, e que os seus descendentes se misturam com o nosso povo. Onde ele não chegou ainda, o país apresenta o aspecto com que surpreendeu os seus primeiros descobridores. Tudo o que significa luta do homem com a natureza, conquista do solo para a habitação e cultura, estradas e edifícios, canaviais e cafezais, a casa do senhor e a senzala dos escravos, igrejas e escolas, alfândegas e correios, telégrafos e caminhos de ferro, academias e hospitais, tudo, absolutamente tudo que existe no país, como resultado trabalho manual, como emprego de capital, como acumulação de riqueza, não passa de uma doação gratuita da raça que trabalha à que faz trabalhar.

Por esses sacrifícios sem número, por esses sofrimentos, cuja terrível concatenação com o progresso lento do país faz da história do Brasil um dos mais tristes episódios do povoamento da América, a raça negra fundou, para outros, uma pátria que ela pode, com muito mais direito, chamar sua. Suprima-se mentalmente essa raça e o seu trabalho, e o Brasil não será, na 
sua maior parte, senão um território deserto, quando muito um segundo Paraguai, guarani e jesuítico.

Nessas condições é tempo de renunciarmos ao usufruto dos últimos representantes dessa raça infeliz. Vasconcelos, ao dizer que nossa civilização viera da costa d'África, pôs patente, sem querer, o crime do nosso país escravizando os próprios que o civilizaram. Já vimos com que importante contingente essa raça concorreu para a formação do nosso povo. A escravidão moderna repousa sobre uma base diversa da escravidão antiga: a cor preta. Ninguém pensa em reduzir homens brancos ao cativeiro: para este ficaram reservados tão somente os negros. Nós não somos um povo exclusivamente branco, e não devemos portanto admitir essa maldição pela cor; pelo contrário, devemos tudo fazer por esquecê-la.

A escravidão, por felicidade nossa, não azedou nunca a alma do escravo contra o senhor - falando coletivamente - nem criou entre as duas raças o ódio recíproco que existe naturalmente entre opressores e oprimidos. Por esse motivo, o contato entre elas sempre foi isento de asperezas, fora da escravidão, e o homem de cor achou todas as avenidas abertas diante de si. Os debates da última legislatura, e o modo liberal pelo qual o Senado assentiu à elegibilidade dos libertos, isto é, ao apagamento do último vestígio de desigualdade da condição anterior, mostram que a cor no Brasil não é, como nos Estados Unidos, um preconceito social contra cuja obstinação pouco pode, o talento e o mérito de quem incorre nele. Essa boa inteligência em que vivem os elementos, de origem diferente, da nossa nacionalidade é um interesse público de primeira ordem para nós.

Ouvi contar que, estando Antônio Carlos a ponto de expirar, um indivíduo se apresentava na casa onde finava o grande orador, instando por vê-lo. Havia ordem de não admitir pessoas estranhas no quarto do moribundo, e o amigo encarregado de executá-las teve que recusar ao visitante esse favor - que ele implorava com água nos olhos - de contemplar antes da morte o último dos Andradas. Por fim, notando a insistência desesperada do desconhecido, perguntou-lhe o amigo que estava de guarda: "Mas por que o senhor quer tanto ver o Sr. Antônio Carlos?" "Por que quero vê-lo?", respondeu ele numa explosão de dor, "Não vê a minha cor! Pois se não fosse os Andradas, que éramos nós no Brasil? Foram eles que nos deram esta pátria!".
Sim, foram eles que deram uma pátria aos homens de cor livres, mas essa pátria, é preciso que nós a estendamos, por nossa vez, aos que não o são. Só assim poder-se-á dizer que o Brasil é uma nação demasiado altiva para consentir que sejam escravos brasileiros de nascimento, e generosa bastante para não consentir que o sejam africanos, só por pertencerem uns e outros à raça que fez do Brasil o que ele é. 